Saudi Journal of Biomedical Research

Abbreviated Key Title: Saudi J Biomed Res ISSN 2518-3214 (Print) |ISSN 2518-3222 (Online)

\title{
Molecular Detection of Virulence Genes among Pseudomonas aeruginosa Clinical Isolates from Khartoum State Hospitals, Sudan
}

\author{
Ashraf Mohammed Abdelrahman ${ }^{1 *}$, Nagla Mohammed Ahmed ${ }^{1}$ \\ ${ }^{1}$ Department of Medical Microbiology, Faculty of Medical Laboratory Sciences, Al-Neelain University, Khartoum, Sudan
}

\author{
DOI: $\underline{\text { 10.36348/sjbr.2021.v06i02.005 }}$ | Received: 02.02.2021 | Accepted: 11.02.2021 | Published: 21.02 .2021 \\ *Corresponding author: Ashraf Mohammed Abdelrahman
}

\section{Abstract}

Pseudomonas aeruginosa possesses a variety of virulence factors that may contribute to its pathogenicity. Dissemination of resistant and highly virulent pathogens is also the main problem worldwide. Thus this study aimed to determine the frequency of oprI, Las B and toxA virulence genes among the clinical isolates of $P$. aeruginosa species. A total of $100 P$. aeruginosa clinical isolates were collected from Hospitals and laboratories from different specimens during the period from August 2019 to November 2020. The isolates were re- identified using routine culture techniques, and multiplex PCR was applied to detect the presence of these virulence genes among them. It was found that the frequency of virulence genes were (22\%) Las B, (55\%) OprI, (15\%) Tox A and (8\%) mixed of OprI and Tox A. These genes were found with different percentage among the studied variables with the higher frequency among males, wound samples, except OprI were among 26-36 years age group and significantly among inpatients than out patients. The study concluded that all isolates carried either one or two of studied genes in different percentage while OprI represented the most predominant gene. Determination of different virulence genes of $P$. aeruginosa isolates suggests that they are associated with different levels of intrinsic virulence and pathogenicity.

Keywords: Molecular detection, Pseudomonas aeruginosa, virulence genes, Khartoum, Sudan.

Copyright (C) 2021 The Author(s): This is an open-access article distributed under the terms of the Creative Commons Attribution 4.0 International License (CC BY-NC 4.0) which permits unrestricted use, distribution, and reproduction in any medium for non-commercial use provided the original author and source are credited.

\section{INTRODUCTION}

Pseudomonas aeruginosa (P. aeruginosa) is an opportunistic pathogen that it considered as a major health hazard, especially in immunodeficient patients [1]. It is most commonly associated with nosocomial diseases [2]. Its infections in hospitals, mainly affect the patients in intensive care units and those having catheterization, burn, and/or chronic illnesses [3]. It possesses a variety of virulence factors that may contribute to its pathogenicity such as exotoxin A, exoenzyme S, nan 1, and Las genes [4]. The outermembrane proteins of $P$. aeruginosa are OprI and OprLthat play an important roles in the interaction of the bacterium with the environment, as well as the inherent resistance of $P$. aeruginosa to the antibiotics. In addition, the presence of the specific outer membrane proteins has been implicated in the efflux transport systems that affect cell permeability $[5,6]$.

Exotoxin A, encoded by the toxA gene, which is the most toxic virulence factor detected in this organism that inhibits protein biosynthesis. It has a necrotizing activity on tissues and contributes to the colonization process [7]. Elastase B (lasB) is a multifunctional metalloenzyme, it influences pathogenesis by enhancing adhesion, colonization, and invasion of tissues, causing chronic pulmonary inflammation [8]. Additionally, elastase B is an important protease of $P$. aeruginosa. This enzyme has a tissue-damaging activity, it can degrade a number of plasma proteins and it contributes to the survival of $P$. aeruginosa in infected tissues [9].

LasB is considered to be a potential target for the development of an innovative chemotherapeutic approach, especially against multidrug-resistant strains [6].

So the present study aimed to detect the frequency of some virulence genes (LasB, OprI and Tox A) of clinical isolates of P.aeruginosa such few studies were carried out in our country.

\section{METHODS}

Design and Setting

This descriptive cross-sectional study encompassed different Khartoum State Hospitals (Soba 
Hospital, Bahri Hospital and Military Hospital) during the period from August 2019 to November 2020.

A total of 100 clinical isolates of P.aeruginosa that have been collected from different clinical specimens were considered for this study. Data in the present study that included patient's gender, age, and, types of clinical specimens were obtained from Hospitals records.

\section{Sample Processing}

Colonies from P.aeruginosa clinical isolates were sub-cultured on Nutrient and MacConkey agar media and incubated at $37^{\circ} \mathrm{C}$ for 24 hours to ensure purity and optimal growth. Then they were reidentified using routine culture techniques

\section{Multiplex PCR for detection virulence gene (oprI,toxAand lasB) \\ DNA extraction}

Bacterial DNA was extracted by using physical method (boiling). Two to three colonies of pure culture of $P$. aeruginosa isolates were suspended in $50 \mu \mathrm{L}$ of distal water (D.W) and vortexed to ensure a homogenous suspension.
The suspension was incubated at $94^{\mathrm{O}} \mathrm{C}$ for 10 minutes and then centrifuged. The supernatant was collected in a clean tube and stored at $-20^{\circ} \mathrm{C}$ as a template DNA stock [9].

\section{PCR amplification procedures}

The PCR was carried out by using primers targeting (oprI, toxA and lasB) virulence genes [10]., the PCR assay included $25 \mu \mathrm{l}$ final reaction mixture which consisted $5 \mu \mathrm{l}$ of (taq polymerase, reaction buffer., $\mathrm{MgCl}$ and DNTPs) (Intron biotechnology, Korea) and $2 \mu \mathrm{l}$ of each $10 \mathrm{P}$ mol forward and reverse primers specific for these virulence genes, $5 \mu$ from DNA template and $13 \mu \mathrm{l}$ from $\left(\mathrm{ddH}_{2} \mathrm{O}\right)$ to complete the volume to $25 \mu \mathrm{l}$ final reaction mixture .The reaction tubes were cycled in thermal cycler machine (Techne, England). The PCR program was performed with an initial denaturation for $5 \mathrm{~min}$ at $94^{\circ} \mathrm{C}$, then 35 cycles of denaturation for $1 \mathrm{~min}$ at $94^{\circ} \mathrm{C}$, annealing for $1 \mathrm{~min}$ at $58^{\circ} \mathrm{C}$ and $60^{\circ} \mathrm{C}$ for lasB gene, extension for $1 \mathrm{~min}$ at $72^{\circ} \mathrm{C}$ and final extension for $5 \mathrm{~min}$ at $72^{\circ} \mathrm{C}$. The amplified products were resolved in $\% 2$ agarose gel electrophoresis stained with ethidium bromide and visualized under UV light [10]. Primers used for amplification of virulence genes of $P$. aeruginosa isolates as in Table-1.

Table-1: The amplified primers used in the present study

\begin{tabular}{|l|l|l|}
\hline Amplified gene & Specific Primer & Amplified region (bp) \\
\hline oprI & $\begin{array}{l}\text { PS1, 5'-ATG AAC AAC GTT CTG AAA TTC TCT GCT-3' } \\
\text { PS2, 5'-CTT GCG GCT GGC TTT TTC CAG-3' }\end{array}$ & $\mathbf{2 5 0}$ \\
\hline tox $\boldsymbol{A}$ & $\begin{array}{l}\text { Toxf 5' GGT AAC CAG CTC AGC CAC AT 3' } \\
\text { tox r 5' TGA TGT CCA GGT CAT GCT TC 3' }\end{array}$ & $\mathbf{3 5 2}$ \\
\hline lasB & $\begin{array}{l}\text { lasF 5' GGA ATG AAC GAA GCG TTC TC 3' } \\
\text { lasR 5' GGT CCA GTA GTA GCG GTT GG 3' }\end{array}$ & $\mathbf{3 0 0}$ \\
\hline
\end{tabular}

\section{Statistical Analysis}

Data were analyzed by the statistical package of social science (SPSS) soft program version 22, with reference $\mathrm{p}$-value (0.05), P-value $\leq .05$ conceder as significant result. Frequencies and percent obtained in frequency tables, chi-square test for goodness of fit used to test these frequencies. The relations between variables tested using cross tables and chi-square (Fisher exact) test for independence

\section{Ethical Statement}

Ethical approval for this study was obtained from Al-Neelain University Ethical Committee, and informed consent was obtained from the mentioned hospitals.

\section{RESULTS \\ Demographical Data}

Hundred (100) P.aeruginosa clinical isolates were collected from different Hospitals in Khartoum State, Sudan during the period from August 2019 to November 2020. They were obtained from different clinical samples (wound swabs, urine and ear swabs), their identification was confirmed using conventional bacteriological techniques. The isolates were collected from patients from both males (60) and females (40) with age range from 15 to 58 years with a mean age of 43.7 year;

\section{Multiplex PCR result}

The amplified PCR results (Figure-1) revealed that all $P$. aeruginosa isolates carried either one or two of studied genes in different percentage, whereas OprI represented the most predominant gene $(55 \%)$ (Figure2). 

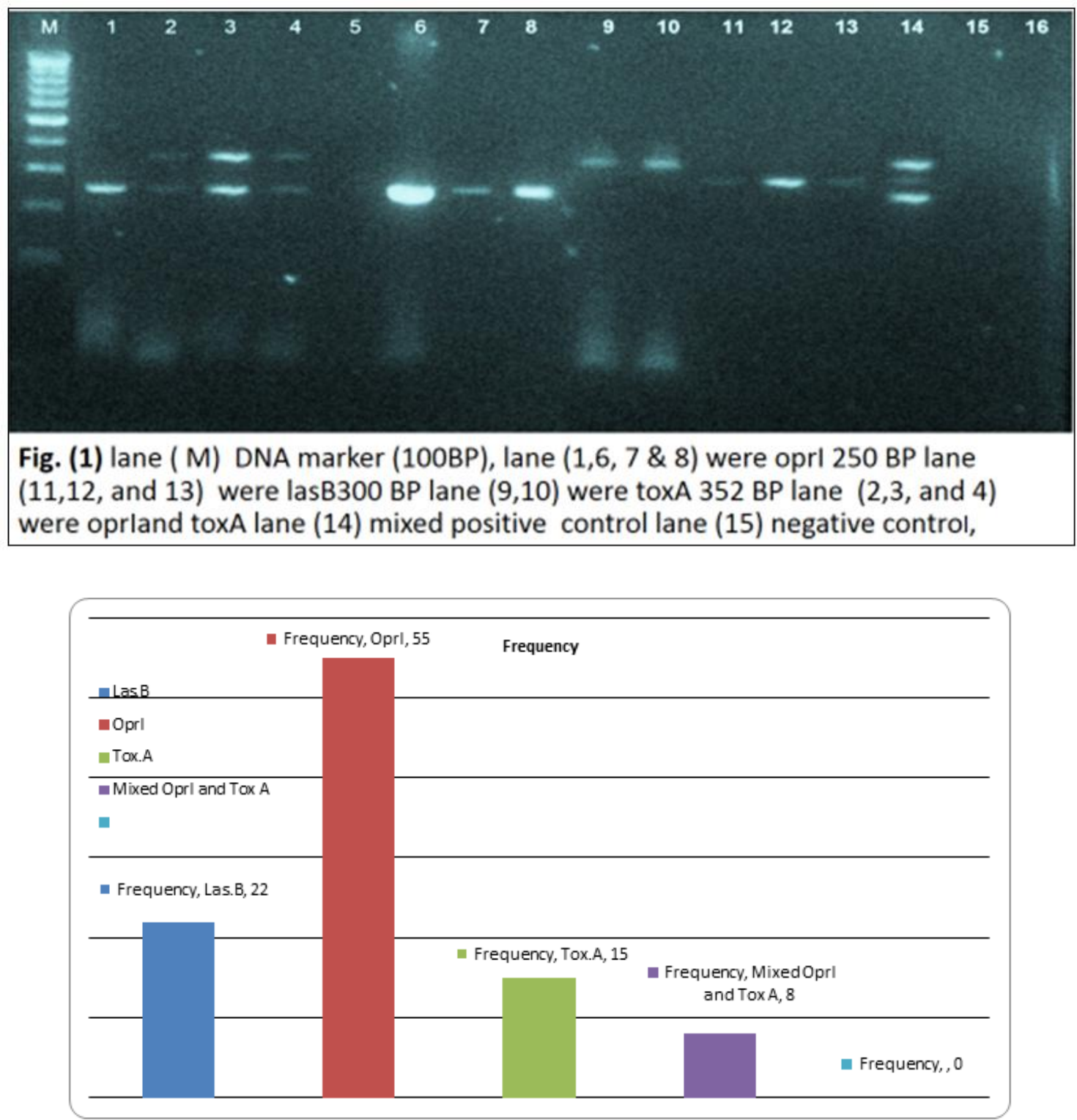

Fig-2: Frequency of virulence genes among P.aeruginosa clinical isolates

Frequency of studied virulence genes according to gender, type of samples, age group and hospital stay Among the $22(22 \%)$ detected Las B, 17(77.2\%) were detected among males which is the most predominant among them followed by mixed of
OprI and ToxA 6/8(75\%), Tox.A 10/15(66.7\%) and Oprl 27/55(49\%). In contrast Oprl was the most predominant $28(51 \%)$ among females followed by ToxA 5(33\%), mixed of OprI and ToxA 2(25\%) and Las B 5(22\%) (Table-2).

Table-2: Frequency of virulence genes among gender

\begin{tabular}{|c|c|c|c|c|c|c|c|}
\hline & \multicolumn{2}{|r|}{ Males } & \multicolumn{2}{|r|}{ Females } & \multicolumn{2}{|c|}{ Total } & P.value \\
\hline Genes & $\mathbf{N}$ & $\%$ & $\mathbf{N}$ & $\%$ & $\mathbf{N}$ & $\%$ & \\
\hline Las B & 17 & $77.20 \%$ & 5 & $22.80 \%$ & 22 & $100 \%$ & 0.09 \\
\hline Oprl & 27 & $49 \%$ & 28 & $51 \%$ & 55 & $100 \%$ & \\
\hline Tox.A & 10 & $66.70 \%$ & 5 & $33.30 \%$ & 15 & $100 \%$ & \\
\hline Mixed & 6 & $75 \%$ & 2 & $25 \%$ & 8 & $100 \%$ & \\
\hline
\end{tabular}

The frequencies of the studied genes among the clinical samples were expressed in Table-3. It shows that the most prevalent virulence genes harboring wound swabs, urine and ear swabs were as follow: Las B (72.7\%), mixed of OprI and ToxA $(50 \%)$ and Oprl
(21.8) respectively. Although Oprl was the least common among wound specimens it was the second most common among urine $(32.7 \%)$ specimens and Las $\mathrm{B}$ was not detected among isolates from ear swabs $(\mathrm{P}$ value $>0.05)$. 
Table-3: Frequency of virulence genes according to type of samples

\begin{tabular}{|c|c|c|c|c|c|c|c|c|c|}
\hline & \multicolumn{2}{|c|}{ Wound } & \multicolumn{2}{|c|}{ Urine } & \multicolumn{2}{|c|}{ Ear swab } & \multicolumn{2}{|c|}{ Total } & P.value \\
\hline Genes & $\mathbf{N}$ & $\%$ & $\mathbf{N}$ & $\%$ & $\mathbf{N}$ & $\%$ & $\mathbf{N}$ & $\%$ & 0.07 \\
\hline Las B & 16 & $72.70 \%$ & 6 & $27.30 \%$ & 0 & 0 & 22 & $100 \%$ & \\
\hline Oprl & 25 & $45.50 \%$ & 18 & $32.70 \%$ & 12 & $21.80 \%$ & 55 & $100 \%$ & \\
\hline Tox.A & 10 & $66.70 \%$ & 2 & $13.30 \%$ & 3 & $20 \%$ & 15 & $100 \%$ & \\
\hline Mixed & 4 & $50 \%$ & 4 & $50 \%$ & 0 & 0 & 8 & $100 \%$ & \\
\hline
\end{tabular}

The clinical isolates were collected from patients with different age group. They were categorized into four group to detect the prevalence of these virulence genes among them as shown in Table-4, which it reflects that, all of studied virulence genes were detected among the four group, with the commonest genes, mixed of OprI and ToxA (25\%) among both the age group (15-25) and (48-58) year, Tox.A (47\%), and lasB (40.1\%) among the age group (26-36) and (37-47) year respectively (P value $>0.05)$

Table-4: Distribution of studied virulence genes according to Age group

\begin{tabular}{|c|c|c|c|c|c|c|c|c|c|c|c|}
\hline & \multicolumn{2}{|c|}{$15-25$ years } & \multicolumn{2}{|c|}{ 26-36 years } & \multicolumn{2}{|c|}{ 37-47 years } & \multicolumn{2}{|c|}{ 48-58 years } & \multicolumn{2}{|c|}{ Total } & P.value \\
\hline Genes & $\mathbf{N}$ & $\%$ & $\mathbf{N}$ & $\%$ & $\mathbf{N}$ & $\%$ & $\mathbf{N}$ & $\%$ & $\mathbf{N}$ & $\%$ & 0.89 \\
\hline Las B & 3 & $13.6 \%$ & 9 & $40.1 \%$ & 9 & $40.1 \%$ & 1 & $4 \%$ & 22 & $100 \%$ & \\
\hline Oprl & 13 & $23.6 \%$ & 15 & $27.3 \%$ & 22 & $40 \%$ & 5 & $9.1 \%$ & 55 & $100 \%$ & \\
\hline Tox.A & 3 & $20 \%$ & 7 & $47 \%$ & 4 & $27 \%$ & 1 & $6 \%$ & 15 & $100 \%$ & \\
\hline Mixed & 2 & $25 \%$ & 3 & $37.5 \%$ & 2 & $25 \%$ & 1 & $12.5 \%$ & 8 & $100 \%$ & \\
\hline
\end{tabular}

Our data targeted the hospital stay as a variable to study the prevalence of these virulence genes among in-patients and out-patients and the result was expressed in Table-5. It shows that there was statistically significance association $(\mathrm{P}$. value $=0.05)$ between hospital stay and the distribution of studied virulence genes (Las B, OprI and OprI).

Table-5: Frequency of studied virulence genes according to hospital stay

\begin{tabular}{|c|c|c|c|c|c|c|c|}
\hline & \multicolumn{2}{|c|}{ In patients } & \multicolumn{2}{|c|}{ Out patients } & \multicolumn{2}{|c|}{ Total } & \multirow{2}{*}{$\begin{array}{l}\text { P.value } \\
0.05\end{array}$} \\
\hline Genes & $\mathbf{N}$ & $\%$ & $\mathbf{N}$ & $\%$ & $\mathbf{N}$ & $\%$ & \\
\hline Las B & 17 & $77.2 \%$ & 5 & $22.8 \%$ & 22 & $100 \%$ & \\
\hline Oprl & 24 & $43.6 \%$ & 31 & $56.4 \%$ & 55 & $100 \%$ & \\
\hline Tox.A & 9 & $60 \%$ & 6 & $40 \%$ & 15 & $100 \%$ & \\
\hline Mixed & 4 & $50 \%$ & 4 & $50 \%$ & 8 & $100 \%$ & \\
\hline
\end{tabular}

\section{DISCUSSION}

Pseudomonas aeruginosa is an opportunistic pathogen capable of infecting virtually all tissues, and possesses a variety of virulence factors that may contribute to its pathogenicity [11]. And it is one of the most common causes of health care- associated infections [12].

In the present study all $P$. aeruginosa clinical isolates represented either one or two of studied genes (Las B, Opr I and ToxA) with the most of isolates (55\%) were remarkably positive for oprI genes which it relatively similar to Ullah et al., [13], who found that oprI was $(40.74 \%)$. Whereas other findings were reported higher percentage $(84.61 \%)$ and $(74.6 \%)$ [13, 14]

Khan and Cerniglia [15] also developed a PCR procedure to detect the prevalence of toxA gene among $P$. aeruginosa by amplifying the toxA gene They reported that of 130 tested $P$. aeruginosa isolates, 125 $(96 \%)$ contained toxAgene, whereas other species of bacteria did not yield any positive results. Qin et al., and Lavenir et al., [16, 17] also reported similar results which they differ from our finding that 15 of 100 isolates own toxA gene. The present finding is relatively similar to other study that reported $(9.9 \%)$ prevalence of ToxA among $P$. aeruginosa [18].

Pathogenicity of $P$. aeruginosa is clearly multifactorial. LasB is one of the most important proteases of $P$. aeruginosa [19]. In this study (22\%) of examined isolates harbored las $B$ gene. This finding is in agreement with previous reports $[13,18]$.

The coexistence of more than one virulence factors within the same isolate was found in this study, similar result was reported by Al-Dahmoshi et al., [20].

The higher percentage of virulence genes (Las B, ToxA and mixed of OprI and ToxA) were detected among males than females (Table-2). This may be due to strains differences and large sample size of males than females ( $60 \%$ vs. $40 \%)$.

The percentage of virulence genes in terms of the site of infection was determined; it was higher in 
wounds followed by urine (P value > 0.05). Similar result was reported in previous study [21].

In the present study the frequency of virulence genes were detected with different percentage among different age group $(\mathrm{P}$ value $>0.05)$ and the higher percentage was observed significantly among inpatients than out-patients group. This may be due to the study that reported, the prevalence of $P$. aeruginosa and its virulence genes depends on various causes consisting nature of places, degree of contamination and type, immune status of individual patients and virulence of strains [22].

\section{CONCLUSION}

Determination of different virulence genes of $P$. aeruginosa isolates suggests that they are associated with different levels of intrinsic virulence and pathogenicity.

The various distributions of virulence genes among the study variables with significant correlation among in-patients group indicates the potential risk of these isolates especially in nosocomial infections, which it reflect the need for further studies to find out the actual role of these genes in different clinical infections caused by $P$. aeruginosa.

Conflict of interests: The authors declared no conflict of interests.

\section{REFERENCES}

1. Nanvazadeh, F., Khosravi, A. D., Zolfaghari, M. R., \& Parhizgari, N. (2013). Genotyping of Pseudomonas aeruginosa strains isolated from burn patients by RAPD-PCR, Burns, 39(7), 14091413.

2. Pang, Z., Raudonis, R., Glick, B. R., Lin, T. J., \& Cheng, Z. (2019). Antibiotic resistance in Pseudomonas aeruginosa: mechanisms and alternative therapeutic strategies. Biotechnology advances, 37(1), 177-192.

3. Davies, J. E. (1997, January). Origins, acquisition and dissemination of antibiotic resistance determinants. In Ciba Found Symp (Vol. 207, pp. 15-27).

4. Anderson, D. (2003). Persistence of antibiotic resistant bacteria. Curr Opin Microbiol, 6, 452456.

5. Fernández, L., Breidenstein, E. B., \& Hancock R. E. (2011). Creeping baselines and adaptive resistance to antibiotics, Drug Resist. Updat, 14, $1-21$.

6. Wong, A., Rodrigue, N., \& Kassen R. (2012). Genomics of adaptation during experimental evolution of the opportunistic pathogen Pseudomonas aeruginosa. PLoS Genet, 8(9), e1002928.
7. Michalska, M., \& Wolf, P. (2015). Pseudomonas exotoxin A: optimized by evolution for effective killing. Front Microbiol, 6, 963.

8. Lanotte, P., Watt, S., Mereghetti L, Dartiguelongue, N.,Rastegar-Lari, A., Goudeau, A., \& Quentin, A. (2004). Genetic features of Pseudomonas aeruginosa isolates from cystic fibrosis patients compared with those of isolates from other origins. J Med Microbiol, 53, 73-81.

9. Nikbin, V. S., Aslani, M. M., Sharafi, Z., Hashemipour, M., Shahcheraghi, F., \& Ebrahimipour, G. H. (2012). Molecular identification and detection of virulence genes among Pseudomonas aeruginosa isolated from different infectious origins. Iran J Microbiol, 4 118-23

10. Nikbin, V. S., Aslani, M. M., Sharafi, Z., Hashemipour, M., Shahcheraghi, F., \& Ebrahimipour, G. H. (2012). Molecular identification and detection of virulence genes among Pseudomonas aeruginosa isolated from different infectious origins. Iranian Journal of Microbiology, 4(3), 118.

11. Van Delden, C., \& Iglewski, B. H. (1998). Cell-tocell signaling and Pseudomonas aeruginosa infections. Emerg Infect Dis, 4, 551-560

12. Fazeli, H., Nasr Esfahani, B., Sattarzadeh, M., \& Mohammadi, B. H. (2017). Antibiotyping and genotyping of Pseudomonas aeruginosa strains isolated from Mottahari Hospital in Tehran, Iran by ERIC-PCR. Infect Epidemiol Microbiol, 3(2), 41-45.

13. Ullah, W., Qasimb, M. R., Rahman, H., Jiec, Y., \& Muhammad, N. (2017). Beta-lactamaseproducingPseudomonas aeruginosa: Phenotypic characteristics and molecular identification of virulence genes. Journal of the Chinese Medical Association, 80, 173-177

14. Adeyemi, F. M., Adeboye, R. R., Adebunmi, A. A., Yusuf, N., \& Wahab, A. A. (2020). Detectionof T3SS, oprI, aprA, and pvdAGenes in Clinical Isolates of Pseudomonas aeruginosa obtained from Wound Samples. Pan African Journal of Life Sciences, 4(1), 17-24

15. Khan, A. A., \& Cerniglia, C. E. (1994). Detection of Pseudomonas aeruginosa from clinical and environmental samples by amplification of the exotoxin A gene using PCR. Appl Environ Microbiol, 60, 3739-3745.

16. Qin, X., Emerson, J., Stapp, J., Stapp, L., Abe, P., \& Burns, L. (2003). Use of real-time PCR with multiple targets to identify Pseudomonas aeruginosa and other nonfermenting gramnegative bacilli from patients with cystic fibrosis. $J$ Clin Microbiol, 4, 4312-4317

17. Lavenir, R., Jocktane, D., Laurent, F., Nazaret, S., \& Cournoyer, B. (2007). Improved reliability of Pseudomons aeruginosa PCR detection by the use of the specific ecfx gene target. $J$ Microbiol Methods, 70, 20-29 
18. Fadhil, L., Al-Marzoqi, A., Zahraa Mohammad, A. 1., Taee, Z. M., \& Shalan, A. S. (2016) Molecular and Phenotypic Study of Virulence Genes in a Pathogenic Strain of Pseudomonas aeruginosaisolated from various clinical origins by PCR: Profiles of genes and Toxins Research. Journal of Pharmaceutical, Biological and Chemical Sciences, 7(1), 590-98

19. Lomholt, J.A., Poulsen, K., \& \& Kilian, M. (2001). Epidemic population structure of Pseudomons aeruginosa: evidence for a clone that is pathogenic to the eye and that has a distinct combination of virulence factor. Infect Immun, 69, 6284-6295
20. Al-Dahmoshi, H. O. M., Al-Khafaji, N. S., Jeyad, A. A., Shareef, H. K., \& Al-Jebori, R. F. (2018). Molecular Detection of Some Virulence Traits among Pseudomonas aeruginosa Isolates. HillaIraq. Biomed Pharmacol J, 11(2).

21. Elmaraghy. N., Abbadi, S., Elhadidi, G., Hashem, A., \& Yousef, A. (2019). Virulence Genes in Pseudomonas Aeruginosa Strains Isolated at Suez Canal University Hospitals with Respect to the Site of Infection and Antimicrobial Resistance. Int J Clin Microbiol Biochem Technol, 2, 8-19

22. Aljebory, I. S. (2018). PCR Detection of Some Virulence Genes of Pseudomonas aeruginosa in Kirkukcity. Iraq J Pharm Sci Resr, 10(5), 10681071. 